\title{
Cell Bank Maintenance
}

National Cancer Institute

\section{Source}

National Cancer Institute. Cell Bank Maintenance. NCI Thesaurus. Code C112951.

A process that generates and maintains a single pool of cells prepared from a selected cell clone under specific conditions. This involves dispensing the cell sample into multiple containers and storing the sample under specific conditions. 